\title{
2004年新潟県中越地震時に表層地盤の非線形震動増幅特性が 小千谷の木造住宅被害に与えた影響 \\ EFFECTS OF NONLINEAR SITE AMPLIFICATION CHARACTERISTICS ON DAMAGE TO WOODEN HOUSES IN OJIYA DURING THE 2004 MID NIIGATA PREFECTURE EARTHQUAKE
}

\author{
時松 孝 次*, 新井 洋**, 関口徹*** \\ Kohji TOKIMATSU, Hiroshi ARAI and Toru SEKIGUCHI
}

\begin{abstract}
Effects of nonlinear properties of surface soil on the variation in strong ground motion and damage to wooden houses within Ojiya city during the 2004 Mid Niigata Prefecture earthquake, are examined, based on field investigation including boring and microtremor measurements, as well as strong motion observation. It is revealed that the maximum response of wooden houses, i.e., damage level, could mainly be controlled by strong ground motion with a period of about 1-2 s. Such a period range was significantly amplified in the damaged sites due to strong soil nonlinearity while it was not in the slightly damaged sites due to week soil nonlinearity.
\end{abstract}

Keywords: strong ground motion, surface soil, nonlinear, natural period, damage to wooden houses, equivalent-performance response spectrum

強震動，表層地盤，非線形，固有周期，木造住宅被害，性能等価応答スペクトル

\section{1. 序論}

2004 年新潟県中越地震では, 震源域に近い小千谷において, 多くの 木造住宅に被害が生じた。これらの住宅被害について，多くの機関に より様々な調査が行われている.このうち, 地震直後に行われた組織 的な悉皆調査としては，日本建築学会北陸支部災害委員会を中心とし た災害調査WGによる調査 ${ }^{1)}$ と，罹災証明書発行を目的として統一的 な被災度判定訓練を受けた小千谷市職員による調査 ${ }^{2), 3)}$ の 2 件がある. 両者には，調查の目的や方針に明確な違いがあるが，いずれの調査結 果でも，小千谷市の中心市街地に比べて，西および南西側に $1-2 \mathrm{~km}$ 程 度離れた山際の時水・吉谷地区において，木造住宅の被災度が大きく なることが報告されている ${ }^{1-3)}$.このことは，小千谷市の中心市街地と 時水・吉谷地区とでは，本震時の地震動特性が大きく異なっていた可 能性を示唆している.

小千谷市内では, 中心市街地に位置する 3 強震観測点（防災科学技 術研究所 K-NET, 気象庁 JMA, 小千谷総合病院「水仙の家」SSI）におい て, 本震および余震の記録が得られている ${ }^{4-6)}$.いずれの観測点でも， 得られた本震記録の最大加速度および最大速度は $8 \mathrm{~m} / \mathrm{s}^{2}, 0.7 \mathrm{~m} / \mathrm{s}$ を超え る大きな値であったが, 観測点周辺の木造住宅の被災度は比較的小さ
かった ${ }^{1-3), 7)}$.この原因として, 境ら 7)は,これら 3 地点での本震記録 の卓越周期が，いずれも 0.5-0.7 秒以下であり，木造住宅に大きな変形 を生じさせる可能性の高い周期帯（1-2 秒程度）から外れていたこと を指摘している。一方, これら 3 地点の本震拈よび余震記録の周期特 性は, その加速度レベルの増大に伴う卓越周期の伸びを含めて, 地点 ごとに大きく異なっている ${ }^{87,9)}$.この原因として, 時松ら ${ }^{8,9)}$ (4, K-NET, $\mathrm{JMA}$ 地点の表層 $3 \mathrm{~m}$ 程度までの地盤の $\mathrm{S}$ 波速度構造および非線形性の 違いが強く影響したことを指摘している．藤川ら ${ }^{10)}$ も，同様の結論を 報告している，以上から, 小千谷では, 本震時に, 表層地盤の非線形 震動増幅特性が地表での強震動特性（とくに卓越周期の伸び）に強く 影響し, その結果, 場所によっては木造住宅の被害が大きくなった可 能性が推察される.

しかし, 本震時に木造住宅の被害が大きかった時水・吉谷地区では, 表層地盤の $\mathrm{S}$ 波速度構造および非線形性に関する情報が殆ど無く，ま た, 本震あるいは余震の地震記録も無い. このため, 中心市街地と時 水・吉谷地区の木造住宅の被害に大きな差異が生じた要因について, 不明な部分が多い. 近接する複数地域で木造住宅の被害が大きく異な った原因を解明し，表層地盤の非線形震動增幅特性が大地震における

\footnotetext{
* 東京工業大学大学院理工学研究科建築学専攻 教授・工博

** 防災科学技術研究所 研究員 - 博士 (工学)

*** 千葉大学大学院工学研究科建築・都市科学専政 助教・博士 (工学)
}

Prof., Dept. of Architecture and Building Engineering, Graduate School of Science and Engineering, Tokyo Institute of Technology, Dr. Eng.

Research Engineer, Nat'l Res. Inst. for Earth Science and Disaster Prevention, Dr. Eng. Assist. Prof., Dept. of Architecture and Urban Science, Graduate School of Engineering, Chiba University, Dr. Eng. 
木造住宅の被害程度を左右する可能性について検討しておくことは, 今後の地震工学・防災に資する研究事例として重要と考えられる.

以上の背景から, 本論文では, 小千谷市の中心市街地と時水・吉谷 地区において, 微動の移動 1 点観測と地震動の同時多点観測を行い, 表層地盤の微小ひずみレベルにおける線形震動（S 波）増幅特性（以 下, $\mathrm{S}$ 波増幅特性) の差異を把握する。次に, 地震観測点のボーリン グ調査および微動アレイ探査を行い, 表層地盤構造をモデル化し, そ の結果に基づく地震応答解析から, 表層地盤の非線形震動増幅特性が 本震時の地震動特性および木造住宅被害に与えた影響を検討する。

\section{2. 小千谷の木造住宅被害率分布の概要}

小千谷市が実施した住宅被害の悉皆調査 ${ }^{2)}$ の結果は，緯度方向 7.5 秒，経度方向 11.25 秒の $1 / 4$ 基準地域メッシュ（昭和 48 年行政管理庁 告示第 143 号：約 $250 \mathrm{~m}$ 四方）ごとに集計されている31. 図 1 に，小 千谷市の中心市街地と時水・吉谷地区を含む地域における各メッシュ の住宅全壊率の分布 ${ }^{3)}$ を0-100m の標高とともに示す.メッシュを表 示していない部分では, 住宅の数が少ないか，あるいは住宅が無いた め，被害率が算定されていない，また，文献 2),3)では，構造種別ごと の住宅被害率が算定されていない.しかし,この地域の住宅の構造種 別は，木造 $92 \%, \mathrm{~S}$ 造 5\%, RC 造 $2 \%$, その他 $1 \%$ となっており ${ }^{3)}$ ，木造 住宅の割合が極めて高い。このため, 本論文では, 文献3)の住宅被害 率を，近似的に，木造住宅の被害率として用いることとする。

図1から，小千谷市では木造住宅の被害は広範囲にわたって発生し たが，全壊率は，3 強震観測点（K-NET, JMA, SSI）が位置する中心市 街地よりも，西および南西側の時水・吉谷地区において高 くなる傾向が認められる．図 2(a), (b)に，吉谷地区と中心 市街地を南南西一北北東に縦断する A-A'ライン（図 1) に沿うメッシュの住宅の課税台帳に基づく建設年 ${ }^{31}$ および 悉皆調査加得られた被害率（全壞，大規模半壤，半壤， 一部損壊） ${ }^{3)}$ の分布を示す．図には，時水・吉谷地区のW2， W3 地点（図 1) を含むメッシュの住宅被害率 ( ラインに投影して示している. 図 2(b)加ら, 中心市街地 $(\mathrm{C} 1$, C3 および JMA 地点周辺) では，半壤以上の被害率は 2-3 割程度以下であり，全壊被害は殆ど見られない。これに対 して，時水·吉谷地区では，半壊以上の被害率は 9 割程度 以上，全壊率は 4 割程度以上となっている。ここで，住宅 の建設年（図 2(a)）と被害率（図 2(b)）との対比から，時 水・吉谷地区では, 1981 年または 1971 年以前に建てられ た住宅の比率と全壊率が概ね同等の値となっており，建設 年の比較的古い住宅に被害が集中した可能性が示唆される。 しかし，全壊被害が殆ど見られない中心市街地（C1, C3 地

表 1 地震観測点の緯度と経度（世界測地系）

\begin{tabular}{|c|c|c|}
\hline Site & Latitude & Longitude \\
\hline W1 & N $37^{\circ} 17^{\prime} 22.56^{\prime \prime}$ & E $138^{\circ} 46^{\prime} 42.82^{\prime \prime}$ \\
\hline W2 & N $37^{\circ} 17^{\prime} 17.29^{\prime \prime}$ & E $138^{\circ} 46^{\prime} 55.78^{\prime \prime}$ \\
\hline W3 & N $37^{\circ} 17^{\prime} 57.81^{\prime \prime}$ & E $138^{\circ} 46^{\prime} 24.72^{\prime \prime}$ \\
\hline $\mathrm{C} 1$ & N $37^{\circ} 18^{\prime} 03.53^{\prime \prime}$ & E $138^{\circ} 47^{\prime} 10.47^{\prime \prime}$ \\
\hline $\mathrm{C} 2$ & N $37^{\circ} 18^{\prime} 17.46^{\prime \prime}$ & $E 138^{\circ} 47^{\prime} 22.46^{\prime \prime}$ \\
\hline C3 & N $37^{\circ} 18^{\prime} 29.98^{\prime \prime}$ & E $138^{\circ} 47^{\prime} 28.37^{\prime \prime}$ \\
\hline
\end{tabular}

点周辺)でも，1981 年または 1971 年以前に建てられた住宅の比率は, 全壊率が 4 割を超える時水・吉谷地区と同程度かやや小さい程度とな っており，住宅の建設年の違いだけでは両地区の全壊率の違いをすべ

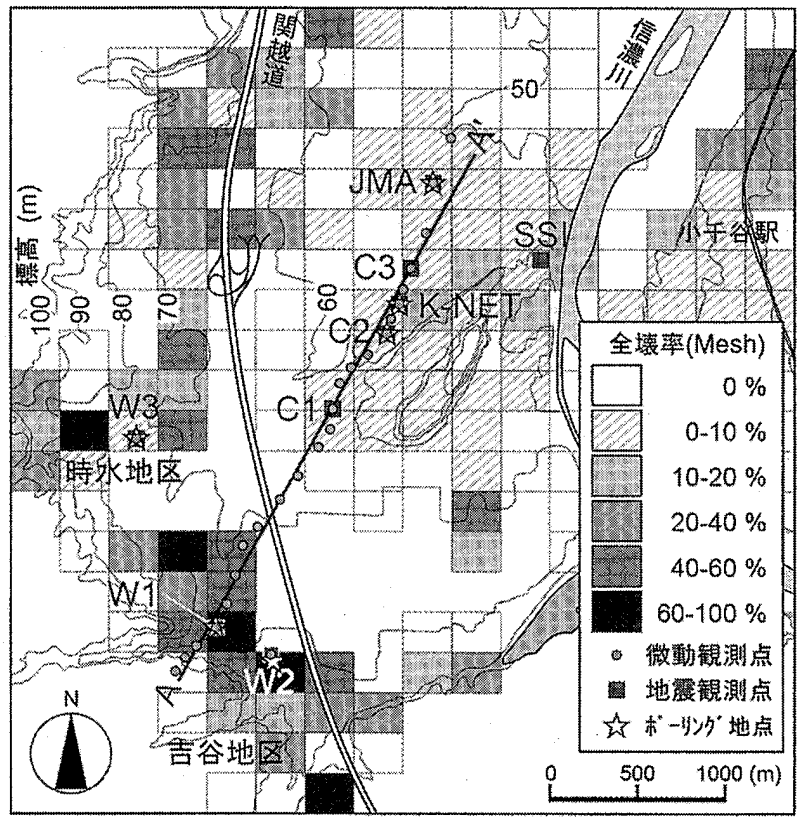

図1 小千谷市の中心部付近における住宅全壊率の分布 ${ }^{3)}$ と微動・地震観測点およびボーリング調查地点
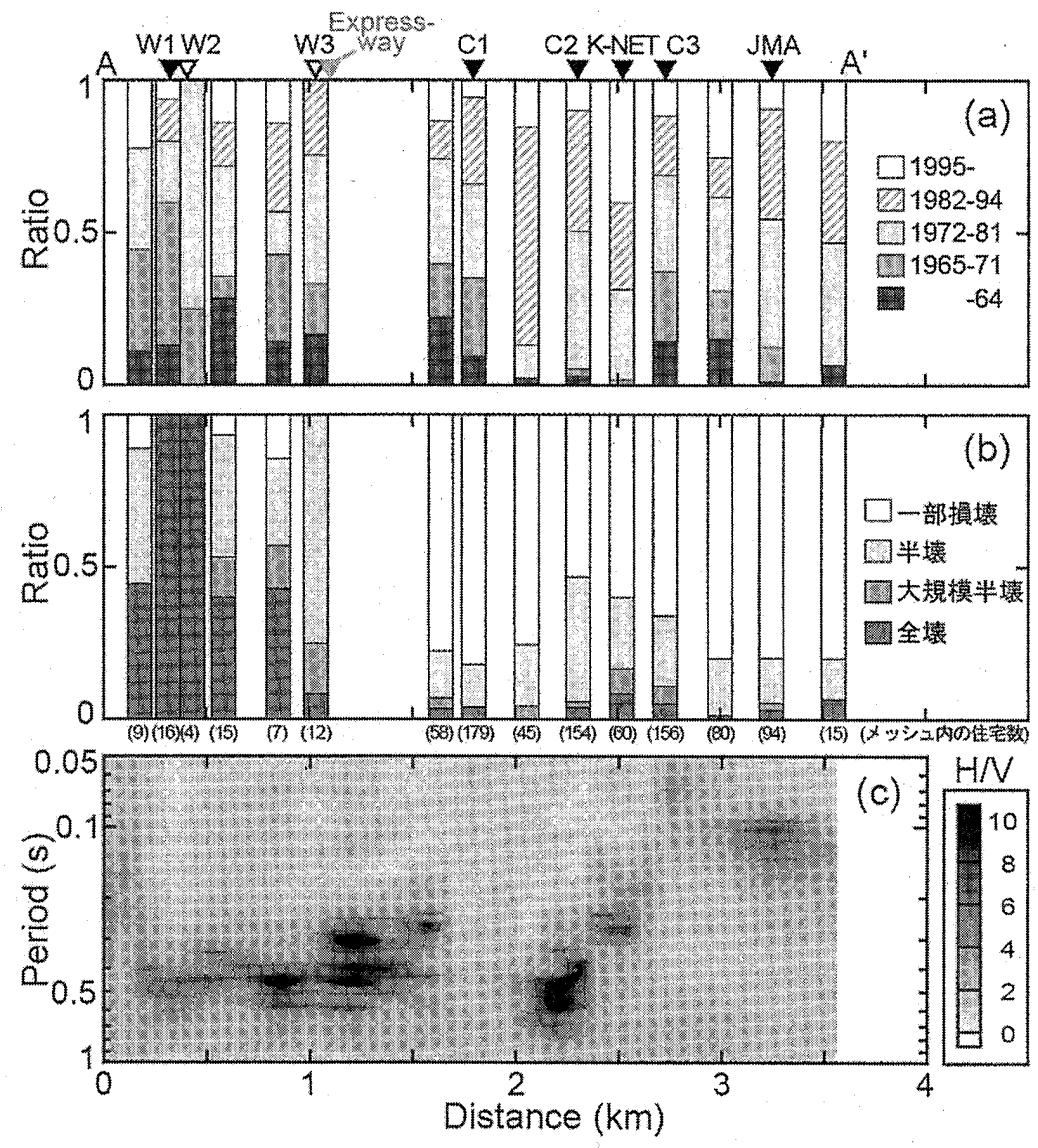

図 2 A-A'ラインに沿う(a)住宅建設年の分布 ${ }^{3)}$, (b)住宅被害率の分布 ${ }^{3)}$ および(c)微動 HN スペクトルの位置的変化 
て説明することはできない.

なお，厚生労働省の調査結果 ${ }^{11\rangle}$ によれば，時水·吉谷地区は軟弱な 地盤上にあるが，木造住宅に被害を与えた可能性のある大きな地盤変 状や液状化の痕跡は報告されていない。このことから，この地域の木 造住宅被害は，主として地盤震動によるものと推察される。

\section{3. 表層地盤のS 波增幅特性と木造住宅被害率との関係}

この地域の地盤の $\mathrm{S}$ 波速度構造および震動特性に関する先験的情報 を把握するため, A-A'ライン上の 24 地点（図 1：O印）においてて, 微 動の移動 1 点観測を行った ${ }^{12)}$. 観測では, 固有周期 2 秒の 3 成分速度 計を用い，サンプリング周波数を 100 ないし $200 \mathrm{~Hz}$ とした。また，木 造住宅被害率の異なる W1-W3, C1-C3 地点（図 1：口印，表 1）におい て，2005 年 11 月から 2007 年 4 月まで地震動の同時観測を行った ${ }^{12)}$. 観測で用いた地震計は(株)東京測振の CV910，サンプリング周波数は

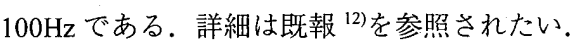

観測された 3 成分微動デー夕に対し，時松・新井 ${ }^{13)}$ と同様の方法で $\mathrm{H} / \mathrm{V}$ スペクトル ${ }^{13)}{ }^{14)}$ を求め，その A-A' ラインに沿う位置的変化を図 2(c)に濃淡で示す. 図 2(b)との比較から, 全壊被害の少ない $\mathrm{C} 1$ および K-NET 地点より東側では, H/V スペクトルに顕著なピークが認められ ないか，あるいは周期 0.1 秒程度以下にピークが認められる。一方， 全壊率の高い時水・吉谷地区では, 周期 0.3-0.5 秒程度に明瞭なピーク が認められる．以上のように，スペクトルピーク周期の長短と木造住 宅被害率の高低との間にはある程度の対応関係が認められる。しかし， C2 地点では，住宅全壤率が低いにもかかわらず，スペクトルピーク周 期が 0.4-0.5 秒程度にあるなど，両者の対応関係は一意ではない.

既往の研究から，K-NET および JMA 地点の微動 H/V スペクトルの ピークは, 各地点の深度 $3 \mathrm{~m}$ 程度までの軟弱層 ( $\mathrm{S}$ 波速度 $50-100 \mathrm{~m} / \mathrm{s}$ 程度）とそれ以深の砂礫層（S 波速度 350-400 $\mathrm{m} / \mathrm{s}$ 程度，いわゆる工学 的基盤）との $\mathrm{S}$ 波速度コントラストを反映していることが指摘されて

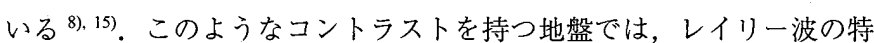
性を反映した微動 $\mathrm{H} / \mathrm{V}$ スペクトルのピーク周期が地盤の $\mathrm{S}$ 波増幅特性 の 1 次固有周期（以下，線形時固有周期）と対応する場合が多い ${ }^{16)}$. したがって，この地域で微動 H/V スペクトルに明瞭なピークが見られ る場合，そのピーク周期は工学的基盤以浅の地盤の線形時固有周期に 近い可能性が高い. 一方, $\mathrm{C} 1$ 地点のように, 顕著なスペクトルピーク が見られない場合, 工学的基盤がほほ露頭していると考えられる ${ }^{16)}$. 一方, ある程度近傍かつ深発の微小地震を対象とすれば, K-NET, JMA, SSI のうち任意の 2 地点の水平動の振幅比スペクトルは, 各地点の工 学的基盤以浅の地盤の S 波堌幅特性のそれに対応している ${ }^{9)}$. 10), 15).

以上の考察から, 同様の微小地震において，この地域の任意地点の $\mathrm{C} 1$ 地点に対する水平動振幅比スペクトルは, その地点の工学的基盤以 浅の地盤の S 波堌幅特性を近似している可能性が高い。そこで, W1-W3，C1-C3 および K-NET 地点で同時記録された 8 個の微小地震 (気象庁マグニチュード $3-5$ 程度, 震央距離 $30 \mathrm{~km}$ 未満, 震源深さ $8 \mathrm{~km}$ 以上）の水平動記録（直交 2 成分）を用いて，各地点の $\mathrm{C} 1$ 地点に対 するフーリエ振幅比スペクトルを求め,図 3 に灰細線で示す.図では, 観測データの $\mathrm{S} / \mathrm{N}$ 比が 10 以上となる周期帯 (0.07-2 秒) のみを示して いる．図から，得られた水平動振幅比スペクトルは，地震により若干 変動があるものの概ね安定した周期特性を示し，その1次ピーク周期 は各地点の線形時固有周期（微動 $\mathrm{H} / \mathrm{V}$ スペクトルのピーク周期, 図 2(c)）とほぼ対応している. したがって, 図 3 の水平動振幅比スペク トルは各地点の表層地盤の $\mathrm{S}$ 波堌幅特性を近似していると考えられる. なお, 住宅全壊率の異なる W1-W3 地点と $\mathrm{C} 2$ 地点の水平動振幅比スペ クトルは, いずれも周期 0.3-2 秒の範囲で, そのピーク周期を含めて, 概ね同様の傾向を示していることから, これらの地点の表層地盤の $\mathrm{S}$ 波増幅特性に大きな違いは無いものと推察される。

\section{4. ボーリング調査および微動アレイ探查に基づく地盤構造}

3 章の検討から, 時水. 吉谷地区 (W1-W3) と $\mathrm{C} 2$ 地点の微動 $\mathrm{H} / \mathrm{V}$ スペクトルおよび表層地盤の $\mathrm{S}$ 波増幅特性に大きな差異は認められな いが，W1-W3 地点の住宅全壤率は C2 地点のそれに比べて極めて高い ことが確認された。この原因を検討するため, 本章では, W1, W3, C2 地点でボーリング調查を, W1-W3, C1-C3 地点で微動アレイ探査を行 い，各地点の表層地盤構造（土質および $\mathrm{S}$ 波速度構造）を把握する. 4.1 ボーリングに基づく土質調査

ボーリング調査は, W1, C2 地点では 2006 年 9 月, W3 地点では 2007 年 2 月に実施した。掘削深度は $\mathrm{N}$ 值 50 以上の磁層が数 $\mathrm{m}$ 現れるまで

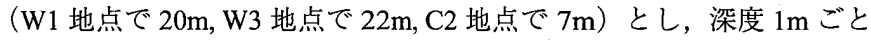
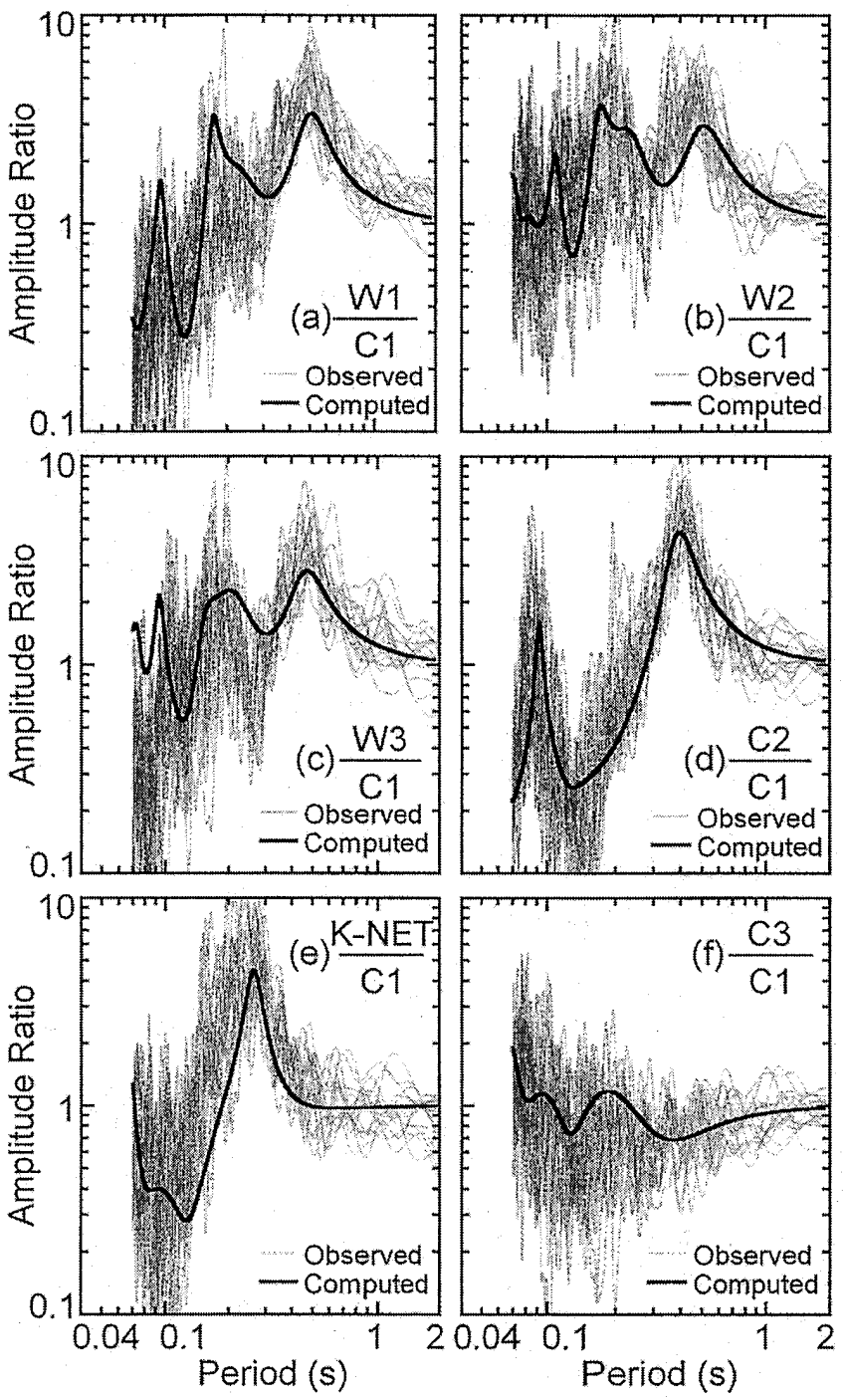

図 3 微小地震の水平動および表層地盤の S 波增幅特性の C1 地点に対する振幅比スペクトル 
に標準貫入試験（自動落下法）を行い，採取された土試料に対して粒 度試験など各種土質試験を行った。

調査から得られた $\mathrm{W} 1, \mathrm{~W} 3, \mathrm{C} 2$ 地点の $\mathrm{N}$ 值および土質の深さ方向分 布を図 4(a), (c), (d)に, (b) W2, (e) K-NET, (f) JMA 地点の調査結果 ${ }^{8)}$ と ともに示す。図から, C2 地点では K-NET 地点と同様に $\mathrm{N}$ 值 10 未満 の高有機質土を含む軟弱な層が $5 \mathrm{~m}$ 程度, W1-W3 地点（時水・吉谷地 区）では $\mathrm{N}$ 值 50 未満のシルト質粘土・シルト・砂からなる層が $15-20 \mathrm{~m}$ 程度以上，硬質な砂磁層（ $\mathrm{N}$ 值 50 以上）の上に堆積しており，時水 . 吉谷地区と $\mathrm{C} 2$ 地点の表層地盤の構造および土質は大きく異なってい ることが確認される.

\section{2 微動アレイ観測に基づくS 波速度構造探査}

W1-W3，C1-C3 地点の微動のアレイ観測は，2006 年 5 月の日中に行 った。アレイの形状は直線（セン开間隔：0.5, 1,2m）および中心 1 点 を持つ 5 角形 (等価半径: 全地点で $5,10,20 \mathrm{~m}, \mathrm{~W} 1-\mathrm{W} 3$ 地点ではさらに 40m）とした．各アレイともセンサには固有周期 1 秒の 3 成分速度計 6 台を用い，センサ間隔あるいは等価半径を変えながら，アレイごと に微動を同時観測した．観測波形は増幅後, サンプリング周波数 100$1000 \mathrm{~Hz}$ で A/D 変換（24bit）した. 記録波形が定常性を保っていると 考えられる区間を選び，各成分 2048 ないし 4096 ポイントのデー夕を 10-30 セット程度作成して，以後の解析に用いた。

各地点で得られた鉛直動データセットに対して，F-k スペクトル解 析 ${ }^{16)}$. 17)を行い，周期一位相速度の関係（分散曲線）を求めた（図 5). また，各地点の最大アレイの中心で得られた 3 成分データセットに対 して，3 章と同じ方法で $\mathrm{H} / \mathrm{V}$ スペクトルを求めた（図 6）..各地点で 得られた分散曲線および $\mathrm{H} / \mathrm{V}$ スペクトルが，それぞれレイリー波拉よ び表面波（レイリー波とラブ波）によるものと考え ${ }^{13)}$, 16), 18), 19), 高次モ ードの影響を考慮した同時逆解析 ${ }^{20)}$ を行った。この際，各地点の地盤 構造は, 地表から深度 20-30m までは, 図 4 を参考に 3-5 層にモデル化

(a) W1

(b) W2

(c) W3

(d) $\mathrm{C} 2$

(e) K-NET

(f) JMA

Soll SPTN-value Soll SPTN-value Soll SPTN-value
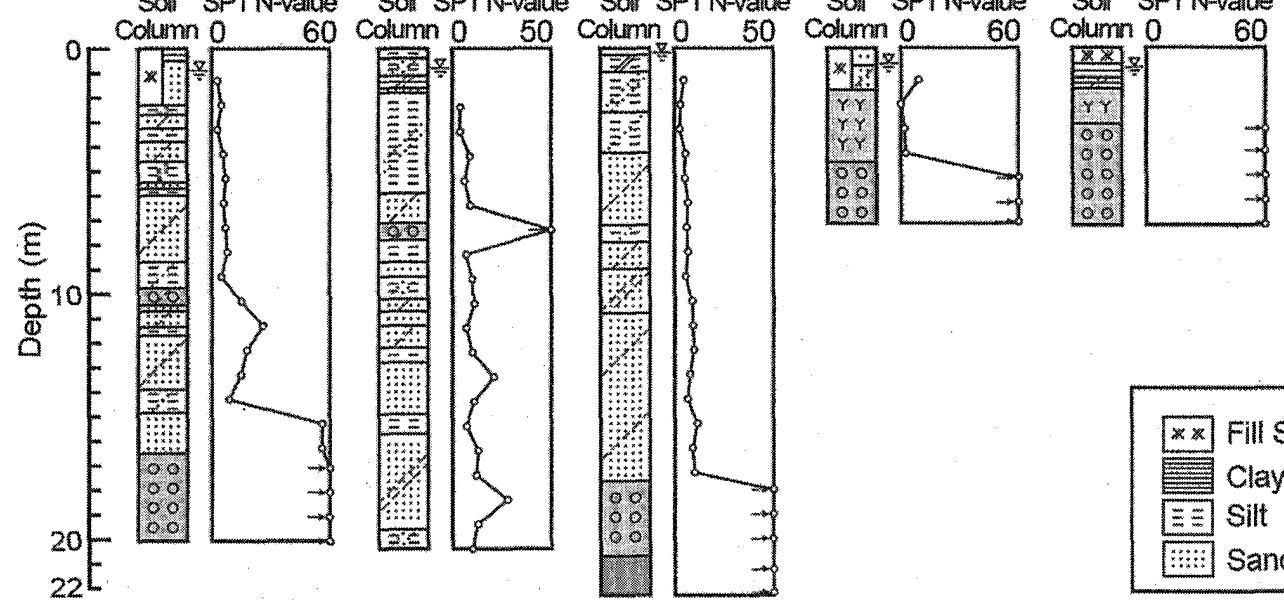

Soll SPTN-value
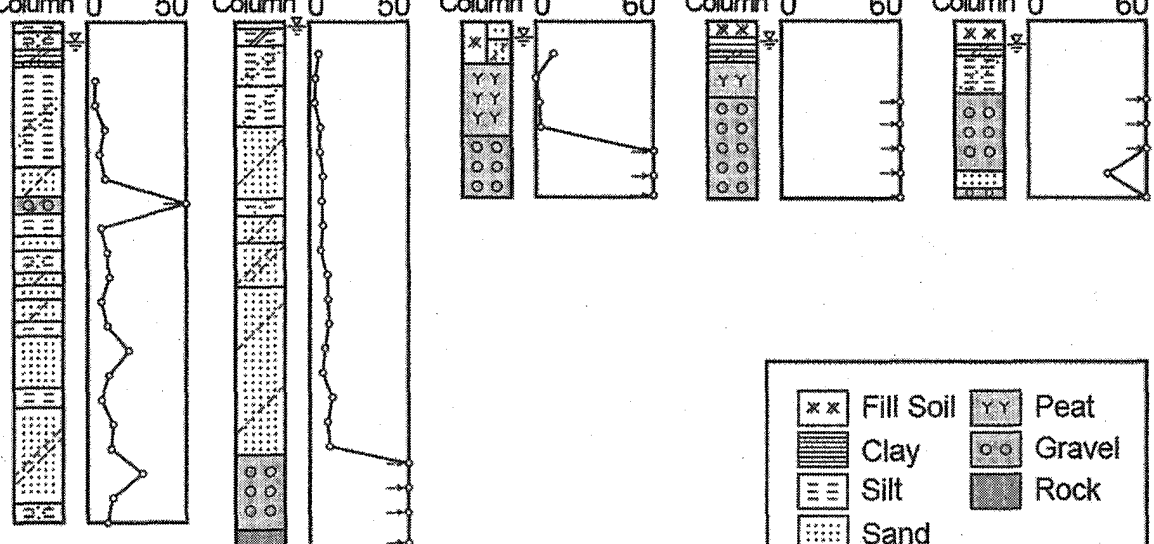

図 4 W1, W2, W3, C2, K-NET ${ }^{8)}, \mathrm{JMA}^{8}$ 地点のボーリング調査結果
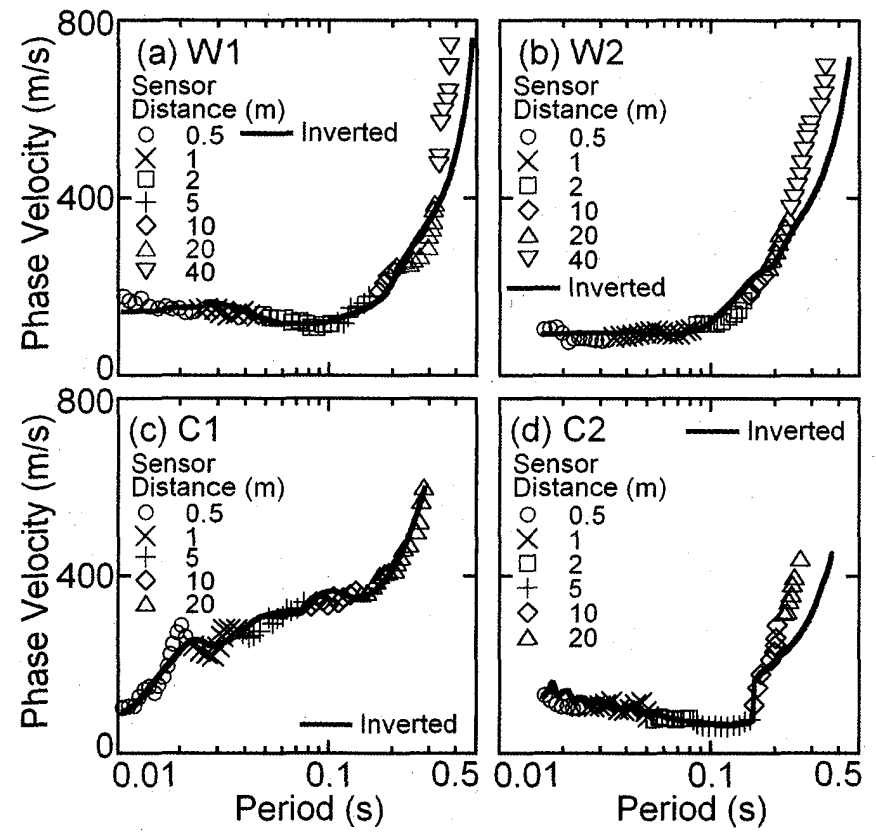

図 5 微動の鉛直成分およびレイリー波の分散曲線
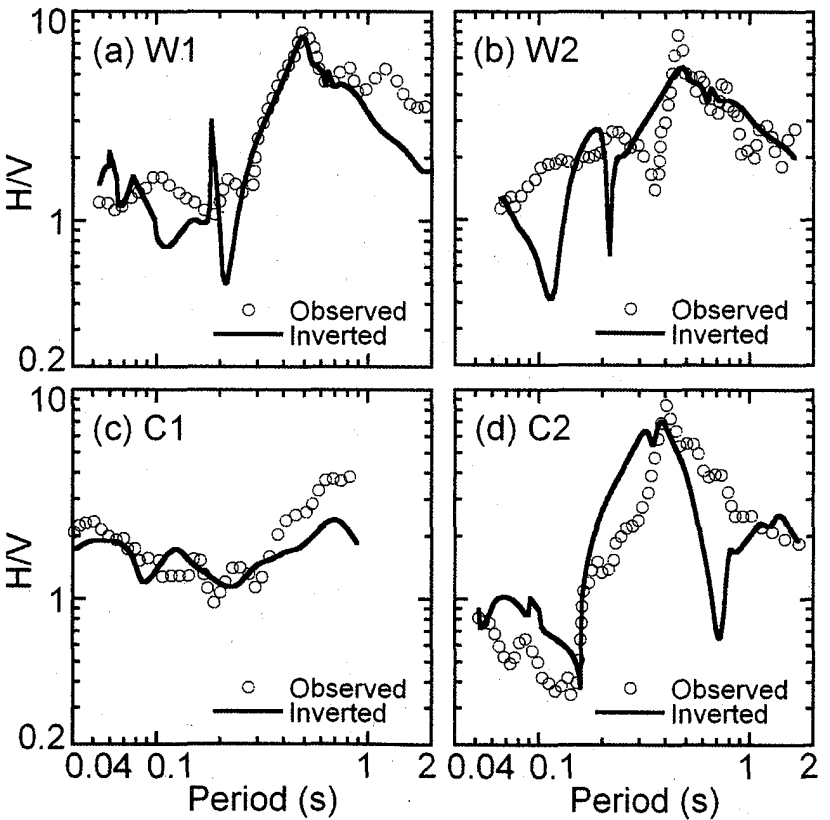

図 6 微動および表面波の $\mathrm{H} / \mathrm{N}$ スペクトル 
した。また，各層の密度と $\mathrm{P}$ 波速度は $\mathrm{S}$ 波速度の関数と仮定し，層厚 と S 波速度を逆解析パラメー夕とした。 なお， H/V スペクトルピーク の理論値を求めるため等に必要となる深度 20-30m 以深の地盤構造は,

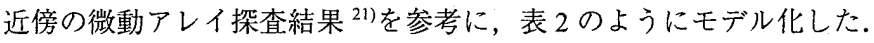

逆解析から推定された W1-W3，C1-C3 地点の表層地盤の $\mathrm{S}$ 波速度構 造を図 7 に示す. 図には, 別途行った K-NET, JMA 地点の微動アレイ 探査結果 ${ }^{15}$ も示す.ここで, 図 5,6の実線は, 各地点の推定地盤構造 に対応するレイリー波の理論分散曲線 ${ }^{16)}$ および表面波の理論 $\mathrm{H} / \mathrm{V}$ スペ クトル ${ }^{13)}$ である。 また，図 3 の黑太線は，各地点の推定地盤構造から 重複反射理論 ${ }^{22}$ （減衰定数 $2 \%$ ）により求めた $\mathrm{S}$ 波増幅特性の $\mathrm{C} 1$ 地点 に対する振幅比スペクトルである. 図 3,5,6 から, 推定地盤構造から 算定した理論值は，微動観測データ，地震観測データの傾向を概ね説 明しており，推定されたS 波速度構造（図 7) の妥当性が示唆される.

図 7 から, 各地点の $\mathrm{S}$ 波速度構造は, $\mathrm{C} 1, \mathrm{C} 3$ 地点を除いて, $\mathrm{S}$ 波速 度 $400 \mathrm{~m} / \mathrm{s}$ 程度以上の工学的基盤とそれよりも浅い層とのコントラス トが明瞭である. 図 7 と図 4 との比較から, $\mathrm{S}$ 波速度 $400 \mathrm{~m} / \mathrm{s}$ 程度以上 の工学的基盤は $\mathrm{N}$ 值 50 以上の砂礫層に対応しており，その上面 深度は，時水・吉谷地区（W1-W3 地点）と C2 地点とでは大きく 異なっていることが確認される.さらに, C2 地点の表層の極めて 低い $\mathrm{S}$ 波速度 $(50 \mathrm{~m} / \mathrm{s})$ 層は高有機質土であることが分かる。

\section{5. 地震応答解析に基づく本震地震動の推定}

4 章の検討から, 時水- 吉谷地区 (W1-W3 地点) と C2 地点の 表層地盤構造（土質および $\mathrm{S}$ 波速度構造）は大きく異なっている ことが確認された．とくに，C2 および K-NET 地点の高有機質土 は，W1-W3 地点の砂やシルトなど他の土質に比べて，S 波速度は 低いが，非線形性が極めて弱い（図 8） 9)。このことから，小千谷 市の中心市街地では, 時水・吉谷地区に比べて, 強震時でも表層 地盤の固有周期が伸びにくく，木造住宅の被害に大きな影響を与 える周期 1-2 秒程度の地震動増幅が小さかったため, 両地区の住 宅全壊湆に大きな差異が生じた可能性が考えられる。

そこで, W1-W3, C1-C3, K-NET, JMA 地点の S 波速度 $400 \mathrm{~m} / \mathrm{s}$ 程 度以下の表層地盤（図7の<印以浅）を対象に，工学的基盤露頭 波と考えられる SSI 地点の本震記録 6), 9), 10) (ほほ主軸方向の EW 成分) を入力として，1 次元有効応力解析を行い, 各地点の本震 地震動を推定した．対象地盤の多質点系モデルへの置換は， $\mathrm{S}$ 波 に対して $10 \mathrm{~Hz}$ 以下の周波数成分を表現できるよう行い，モデル の底面は粘性境界 ${ }^{23)}$ とした。地盤の土質は，W1，W2，W3，C2， K-NET, JMA 地点ではボーリング調査結果（図 4）を, ボーリング 資料の無い $\mathrm{C} 1, \mathrm{C} 3$ 地点では比較的近傍のボーリング資料等を参 考に，図７に示すとおりとした，解析は非排水条件とし，土のせ

表 2 仮定した深部地盤構造

\begin{tabular}{|r|c|c|c|}
\hline Depth $(\mathrm{m})$ & $\rho\left(\mathrm{Mg} / \mathrm{m}^{3}\right)$ & $V_{\mathrm{P}}(\mathrm{m} / \mathrm{s})$ & $V_{\mathrm{S}}(\mathrm{m} / \mathrm{s})$ \\
\hline-50 & 2.0 & $1500-1600$ & $330-470$ \\
\hline $50-300$ & 2.0 & $1800-2300$ & $550-900$ \\
\hline $300-950$ & 2.1 & 2700 & 1200 \\
\hline $950-2800$ & 2.1 & 3100 & 1500 \\
\hline $2800-6000$ & 2.1 & 4000 & 2200 \\
\hline $6000-$ & 2.3 & 6000 & 3400 \\
\hline
\end{tabular}

ん断応力ーひずみ関係には修正 Ramberg-Osgood (R-O)モデル ${ }^{24)}$ ，せん 断に伴う過剩間隙水圧の変化を規定する関係式はおわんモデル 25)を用 いた.この際，修正 R-O モデルの規準ひずみと最大減衰定数は，高有 機質土層では K-NET 地点の室内試験結果（図 8）99を，粘性土・シル 卜・砂・砂礉層では文献 26)を参考に, 拘束圧を考慮して設定した。 図 8 の実線・破線・点線は，各土質に対して設定したせん断剖性比と 隇衰定数のひずみ依存性（拘束圧 $98 \mathrm{kPa}$ ）である。おわんモデルのパ ラメータは, K-NET, JMA 地点については室内試験結果 9の水圧变動を 再現できるよう設定したものを用い，W1-W3，C1-C3 地点のシルト層 についてはJMA 地点と同じものを, 砂礫層については文献 27)の值を 用いた，また, W1-W3 地点の砂質土層については，各層の拘束圧で規 準化した $\mathrm{S}$ 波速度の值が $210 \mathrm{~m} / \mathrm{s}$ 程度を超え, 高い液状化強度を有す ると考えられたため, 文献 28)を参考に, 規準化した S 波速度が $210 \mathrm{~m} / \mathrm{s}$ (適用限界) のときの液状化強度（応力比 1.0 で 10 回載荷したとき両 振幅軸ひずみが $5 \%$ ）と同等となるよう設定した．解析は時刻歴で行 い, 減衰は初期剛性比例型（1 次固有モードの減衰定数 $0.1 \%$ ）とし,

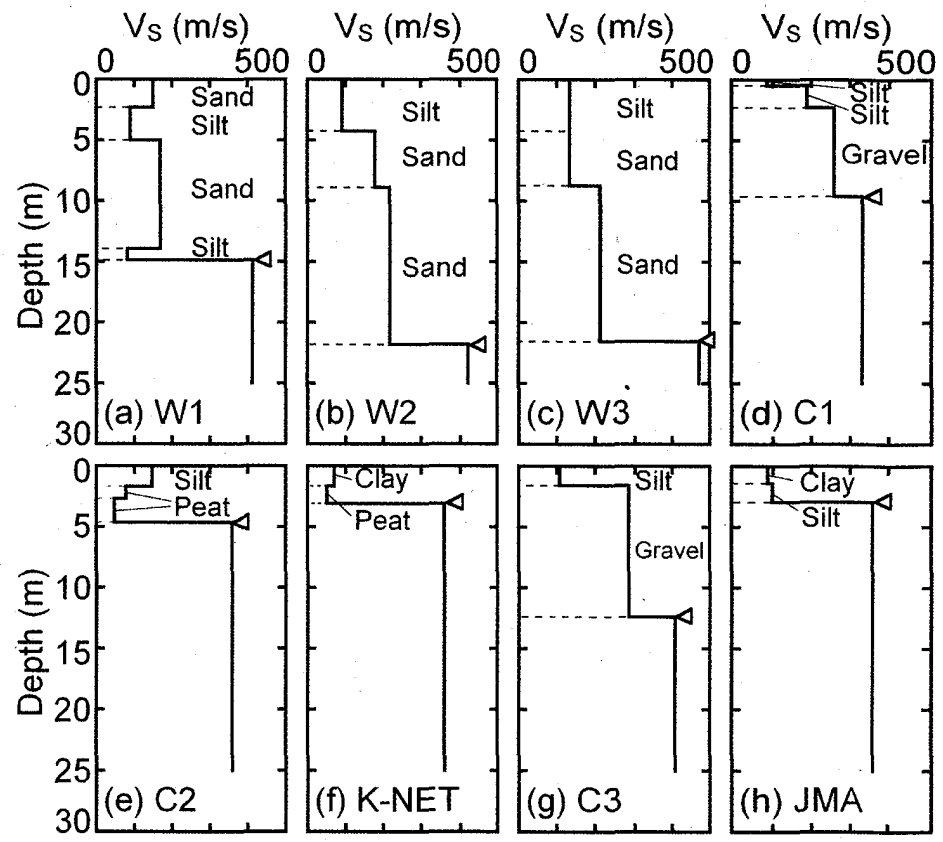

図 7 表層地盤の推定 S 波速度構造および土質

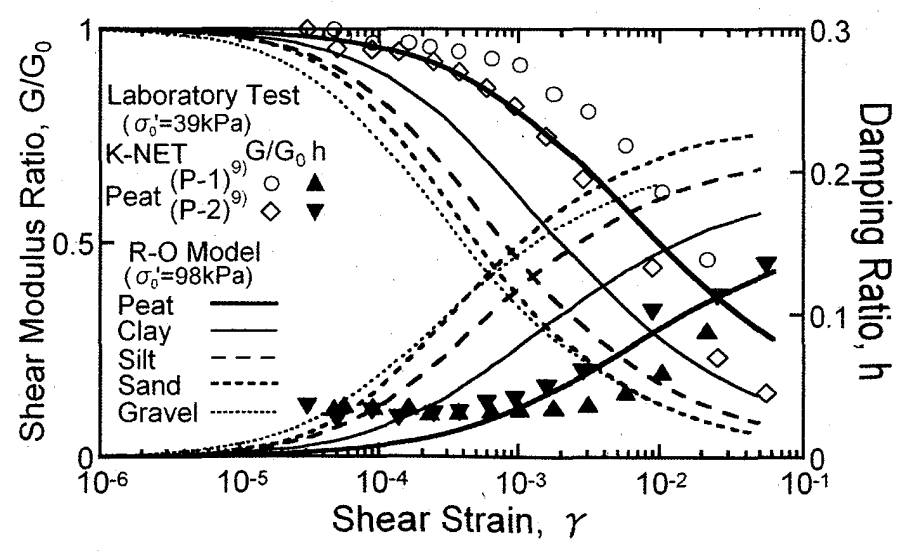

図 8 有効応力解析に用いた土のせん断剛性比と減衰定数の ひずみ依存性および K-NET 地点の室内試験結果 ${ }^{9}$ 
数值積分にはNewmark の $\beta$ 法 ( $\beta=1 / 4$, 時間間隔 $1 / 1000$ 秒)を用いた.

図 9,10 に, 解析加得られた推定地表地震動の加速度時刻歴 (JMA, K-NET, C2, C1，W1 地点）および加速度応答スペクトル（K-NET, JMA 地点:減衰定数 $5 \%$ ）を，それぞれ実線で示す.図 9,10の破線は, K-NET, JMA 地点の本震記録 4)，5（EW 成分）の加速度時刻歷および加速度応 答スペクトル（減衰定数 5\%) である. 図 9,10 から，K-NET, JMA 地 点とも，推定結果は観測結果の振幅および位相・周期特性を概ね再現 できており，解析結果の妥当性が示唆される。また，図 9 から，推定 地表地震動の振幅および位相特性は，地点ごとに大きく異なっている ことが確認される。

図 11 に，解析から得られた W1, W2, C1, C2 地点の表層地盤の非線 形震動堌幅特性（推定地表波と入力波のフーリ工振幅比スペ クトル）を実線で示す. 図の破線は，4.2 節で算定した各地点 の表層地盤の $\mathrm{S}$ 波 (線形震動) 増幅特性である。W1, W2, C2 地点の表層地盤の $\mathrm{S}$ 波增幅特性（図 11 破線）は，各地点の $\mathrm{C} 1$ 地点に対する水平動振幅比スペクトル（図 3）と概ね対応 しており，3 章の議論の妥当性が再確認される.

図 11 から，工学的基盤がほぼ露頭している $\mathrm{C} 1$ 地点では, 線形·非線形時とも, 大きな震動増幅は認められない。一方, $\mathrm{W} 1, \mathrm{~W} 2, \mathrm{C} 2$ 地点では, 比較的大きな震動増幅が認められ，そ のピークとなる 1 次周期（固有周期）は, 線形時には, 各地 点とも 0.4-0.5 秒程度であるが，非線形 (本震) 時には，C2 地点では 0.8 秒程度に伸び, W1, W2 地点では，さらに長周期 化して 1-2 秒程度となっている。ここで，解析から得られた 表層地盤の等価せん断ひずみは， $\mathrm{C} 1, \mathrm{C} 2$ 地点でそれぞれ 0.4 , 5\%程度，それ以外の地点では 1-2\%程度となっている。この ひずみレベルでは，図８から，高有機質土を多く含む C2 お よび K-NET 地点に比べて，砂やシルトを多く含むW1-W3 地

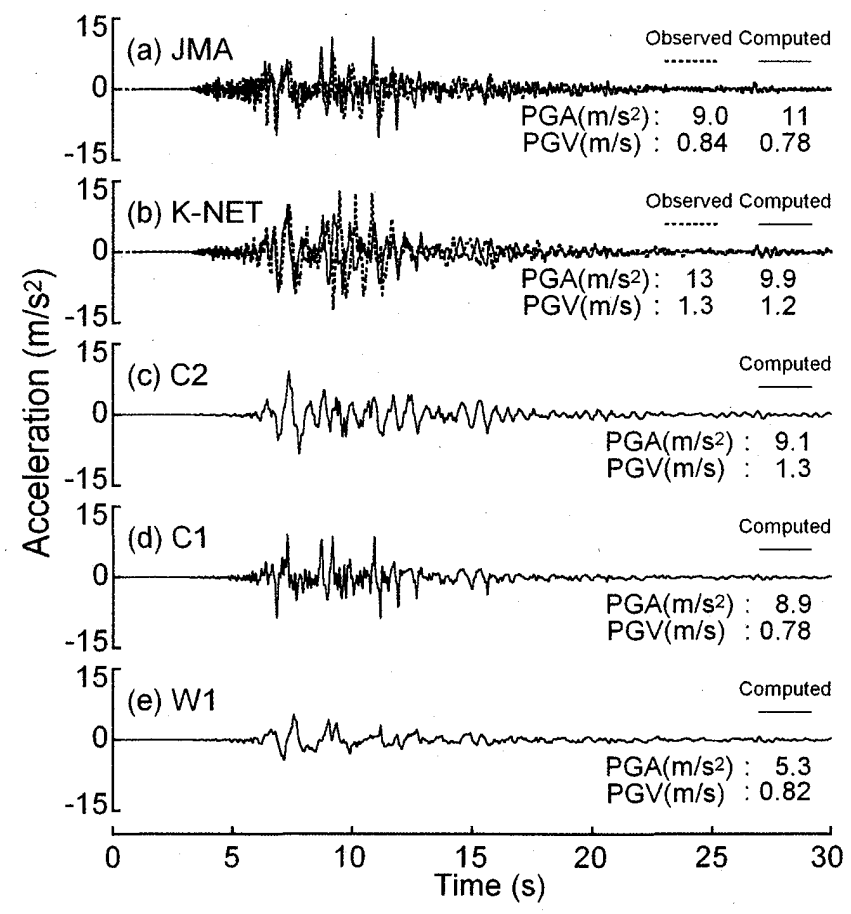

図 9 推定された本震地震動および本震記録 ${ }^{4), 59}$ の 加速度時刻歴 (EW 成分)
点の方が, 地盤のせん断剛性が低下しやすく，固有周期が伸びやすい. したがって，図 11 の固有周期の伸びの違いは，各地点の表層地盤の非 線形性の違いに起因すると考えられる。

図 12 に, W1-W3，C1-C3 地点の解析から得られた推定地表地震動お よび K-NET, JMA 地点の本震記録 ${ }^{4)}$, 5)の加速度応答スペクトル（減衰 定数 $5 \%, \mathrm{EW}$ 成分）を実線・破線・点線で示す．図上部の、印は，各 地点の表層地盤の線形時固有周期を示している. 図から，応答スペク トルの卓越周期についても, 図 11 と同様の傾向が認められる.すなわ

ち, $\mathrm{C} 1, \mathrm{C} 3$ 地点では周期 0.4 秒程度以下の短周期成分が卓越している が，C2 および K-NET 地点ではそれぞれ 0.8, 0.7 秒程度, 'W1-W3 地点 では1-2 秒程度の成分が卓越している。

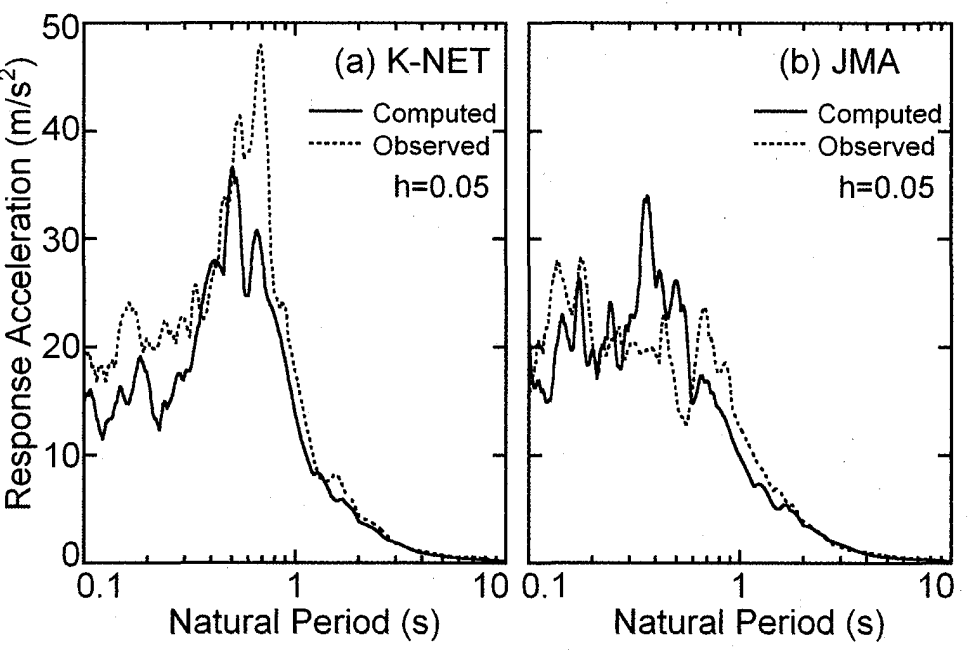

図 10 K-NET, JMA 地点の推定された本震地震動および本震記録 ${ }^{4), 5)}$ の 加速度応答スペクトル（EW 成分）
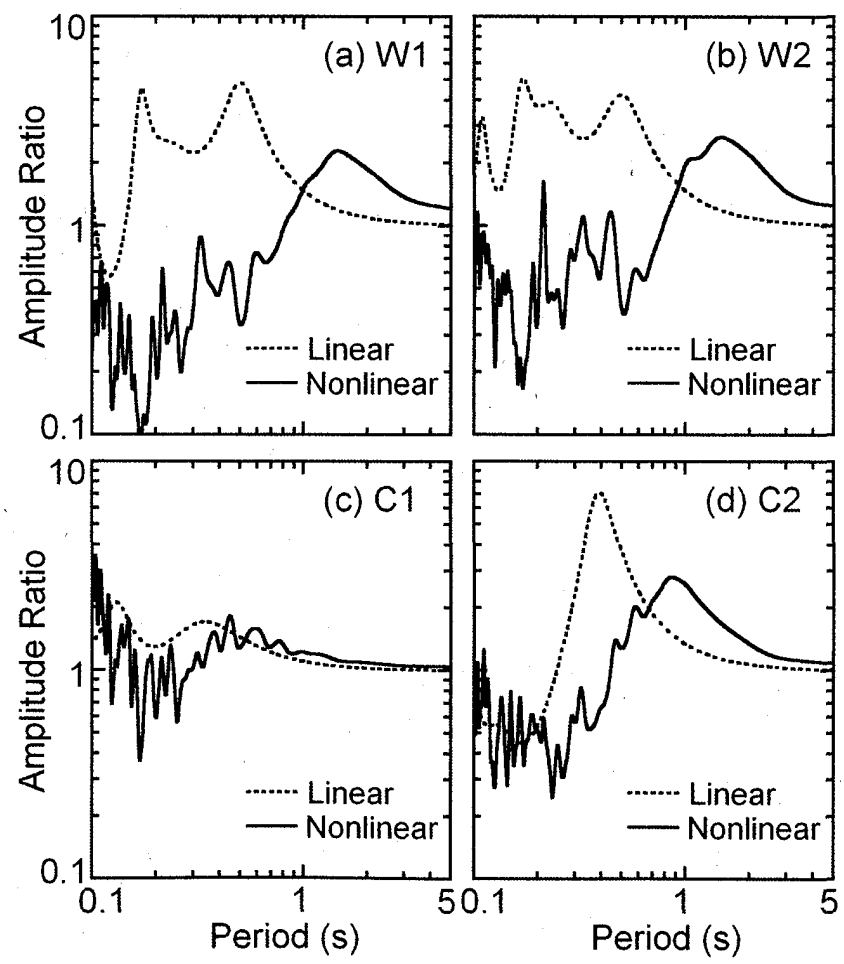

図 11 推定された表層地盤の震動増幅特性 


\section{6. 地盤の固有周期の伸びが木造住宅被害に与えた影響}

本章では, 表層地盤の非線形震動増幅特性が木造住宅被 害に与えた影響を検討するため，5章で推定した W1-W3， C1-C3 地点の本震地震動および K-NET, JMA 地点の本震記 録の加速度応答スペクトル（図 12）から，林 ${ }^{29}$ の提案する 性能等価加速度応答スペクトルに基づき, 各地点の木造住 宅の最大応答変形角 $\mathrm{R}_{\max }$ を推定する。

木造住宅の性能等価加速度応答スペクトルは，住宅を基 礎固定の等価 1 質点系モデルに置換し，その復元力特性を 降伏変形角 $1 / 100$ のバイリニア型と仮定して，与えられた 変形角 $\mathrm{R}$ を住宅の変形限界としたときの地震荷重の換算値 に相当している ${ }^{29)}$ ．したがって，木造住宅の等価高さ $\mathrm{H}_{\mathrm{e}}$ を仮定すれば，性能等価加速度応答スペクトルは，降伏せ ん断力係数（以下，等価耐力） $C_{\mathrm{ye}}$ ごとに，変形角 $\mathrm{R}$ に対 応する固有周期一加速度応答平面上の曲線で表される（図 12)。なお，図の曲線は，1/R が5-100 までの範囲を示して いる.この曲線と地震動の加速度応答スペクトルとの交点 から，木造住宅の最大応答变形角 $\mathrm{R}_{\max }$ および最大応答に最 も寄与する地震動の周期成分が推定される ${ }^{29)}$.

現時点では，小千谷で被災した木造住宅の高さや附力に 関する情報は少ないが，2000 年鳥取県西部地震や 2003 年 宮城県北部の地震で被災した木造住宅の詳細構造調查に基 づく耐震診断結果 ${ }^{30), 31)}$, 同様の木造住宅の調査結果および 載荷試験結果など ${ }^{32-36)}$ から，多くの場合，2 階建て木造住 宅の等価高さは $4-5 \mathrm{~m}$ 程度，等価酎力は 0.2-0.6 程度を中心 に分布していると推察される。そこで，標準的な 2 階建て 木造住宅を想定し, 等価高さ $\mathrm{H}_{\mathrm{e}}=4.5 \mathrm{~m}^{29), 36)}$, 等価耐力 $\mathrm{C}_{\mathrm{ye}}=$ $0.2,0.4,0.6^{33), 36)}$ 持つ木造住宅の性能等価加速度応答スペ クトルを求め,これを図 12 に○付き細線で示す，また，図 12 から, 各地点における想定木造住宅の最大応答変形角 $\mathrm{R}_{\text {max }}$ を等価酎力 $\mathrm{C}_{\mathrm{ye}}$ ごとに求め, その分布を図 13 に示す. 図 13 から, 推定された $R_{\max }$ の值は, $C_{y e}=0.6$ の場合, 0.035 0.065 程度の範囲にあり, W2 地点で最大, $\mathrm{C} 1, \mathrm{C} 3$ 地点で最小となるが, 地区ごとの差異は顕著ではない. しかし， $\mathrm{C}_{\mathrm{yc}}=0.2,0.4$ の場合，中心 市街地の $\mathrm{C} 1, \mathrm{C} 3$ 地点で 0.035 程度, $\mathrm{C} 2$ および K-NET 地点で 0.040-0.065 程度であるのに対して，時水・吉谷地区（W1-W3 地点）では 0.08-0.09 程度と大きくなっている．最大応答変形角 $\mathrm{R}_{\max }$ が大きいほど，木造住 宅に大きな損傷が生じる確率は高くなると考えられる ${ }^{35), 36) こ と か ら ， ~}$ 推定された木造住宅の最大応答变形角 $\mathrm{R}_{\text {max }}$ の分布（図 13）は，住宅被 害率の分布（図 2(b)）．を定性的に再現していると考えられる。

図 12 から, W1-W3 地点の想定木造住宅の最大応答変形角 $\mathrm{R}_{\max }$ が他 の地点のそれよりも大きくなった原因は, W1-W3 地点での推定本震地 震動の周期 1-2 秒程度の成分が他の地点のそれよりも大きかったため と考えることができる。これは，序論に述べた境ら 》の指摘とも調和 的である.この周期 1-2 秒程度の地震動増幅の差異は, 5 章の検討か ら，各地点の表層地盤の固有周期の伸びの違いによるものであり，し たがって, 各地点の木造住宅の最大応答変形角 $\mathrm{R}_{\max }$ および被害率の差 異は，表層地盤の非線形震動増幅特性の違いに大きな影響を受けてい るものと考えられる．参考までに，文献 33)で用いられている標準的 な 2 階建て木造住宅を想定した 2 質点系モデル（基礎固定，1階の降

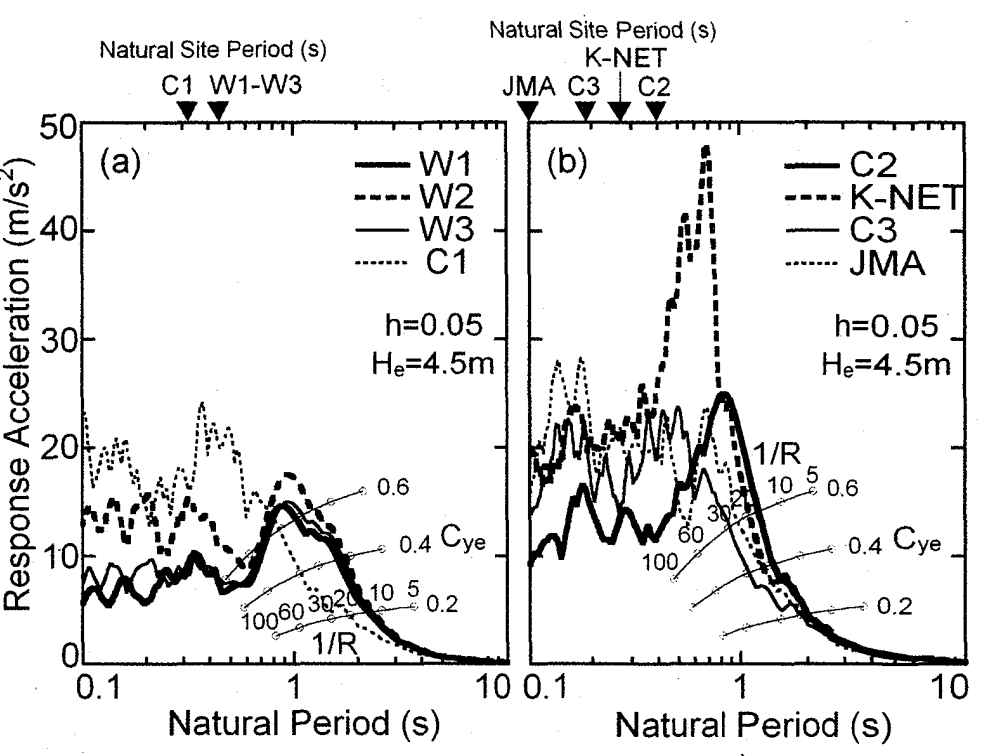

図 12 W1-W3，C1-C3 地点で推定された本震地震動およびK-NET, JMA 地点 の本震記録 ${ }^{4), 5)}$ の加速度応答スペクトル（EW 成分）と標準的な 2 階 建て木造住宅を想定した性能等価加速度応答スペクトル ${ }^{29)} の$ 比較

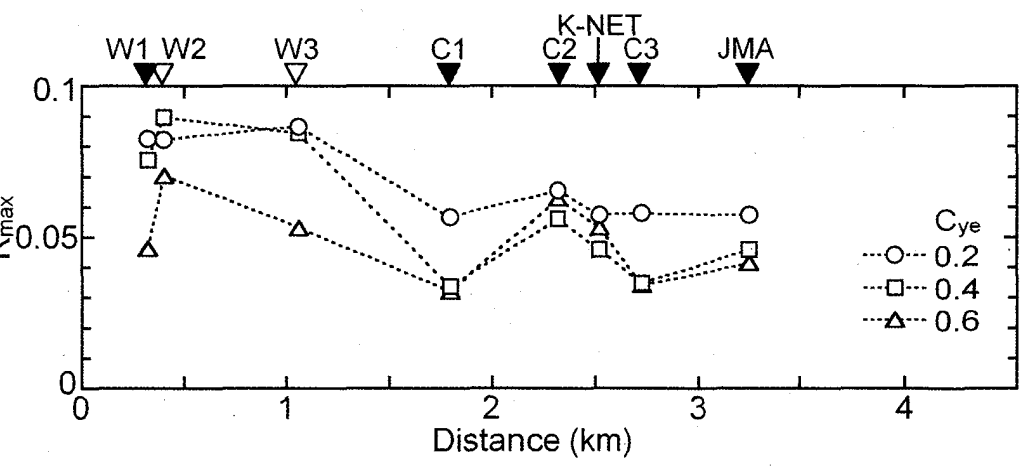

図 13 A-A'ラインに沿う想定木造住宅の最大応答変形角の分布

伏せん断力係数 $=0.2,0.4,0.6)$ に対して, 各地点の推定地表地震動を 入力とした時刻歴非線形応答解析を文献 33) と同等の条件下で行った ところ, 想定木造住宅の最大応答変形角は, 性能等価応答スペクトル による結果（図 13）と概ね整合した。

以上の結果は，5 章の冒頭の仮説「小千谷市の木造住宅の全壊率が 中心市街地に比べて時水・吉谷地区で大きかった原因は, 各地点の表 層地盤の非線形性の差異による周期 1-2 秒程度の地震動増幅の大小, すなわち非線形震動増幅特性（非線形性および $\mathrm{S}$ 波速度構造）の違い が強く影響したためと考えられる.」の妥当性を示している.

なお，本論文では，木造住宅の最大応答変形角 $\mathrm{R}_{\text {max }}$ を推定する建物 解析モデルとして基礎固定の等価質点系 ${ }^{29)}$, 33) を仮定したが, 大地震時 には，建物基礎に接する地盤の局所的な大変形による非線形相互作用 が木造住宅の応答に影響した可能性も考えられる，また，この地域の 木造住宅の耐力, 変形性能, 経年劣化の詳細な情報はほとんど無かっ

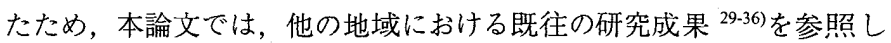
た．小千谷の木造住宅の構造的特徴を反映した等価質点系のモデル化 や，その時刻歴応答と被害との関係については, 今後の課題とし, 別 報で詳細に検討・考察する予定である。 


\section{7. 結論}

2004 年新潟県中越地震時に木造住宅の被害が地区により顕著な相 違の見られた小千谷において，微動・地震観測およびボーリング調查 を行い, その結果に基づく地震応答解析から，表層地盤の非線形震動 增幅特性（非線形性抢よび S 波速度構造）の差異が木造住宅被害に与 えた影響を検討し，以下の結論を得た。

1) 中心市街地と時水·吉谷地区では, 微動の $\mathrm{H} / \mathrm{V}$ スペクトルや表層 地盤の S 波 (線形震動) 増幅特性は同様（いずれも, 周期 0.4-0.5 秒程度にピークを持つ)であったが，木造住宅の被害率は前者に比 ベ後者で極めて大きかった。

2) 中心市街地で本震時の木造住宅被害率が小さかったのは，この地区 の表層地盤が非線形性の弱い高有機質土などを含み, 本震時の固有 周期が木造住宅の被害に大きな影響を与える 1-2 秒程度まで伸びな かったためと考えられる.

3) 時水·吉谷地区で本震時の木造住宅被害率が大きかったのは, 表層 地盤の非線形化により，その固有周期が木造住宅の被害に大きな影 響を与える1-2 秒程度まで伸びたためと考えられる。

\section{謝辞}

本論文で用いた K-NET, JMA, SSI 地点の強震記録は，防災科学技術 研究所, 気象庁, 小千谷総合病院・三菱地所設計 - 大成建設加提供 されたものである.W2 地点のボーリング資料は小千谷市役所から提 供して頂いた，記して謝意を示す。

\section{参考文献}

1) 日本建築学会:2004 年 10 月 23 日新潟県中越地震災害調查報告, $238 \mathrm{pp}, 2006$

2）堀江啓, 重川希志依, 牧紀男, 田中聡, 林春男: 新潟目中越地震に押ける被 害認定調査・訓練システムの実践的検証 一小千谷市のり災証明書発行業務 への適用一, 地域安全学会論文集, No. 7, pp. 123-132, 2005.

3）堀江啓, 林春男, 吉富望, 田中聡：新潟県中越地震に扔矿住家の被害認定 過程に関する一考察 一罹災調査結果を用いた被害分析一, 第 25 回日本自 然災害学会学術講演会, pp. 39-40, 2006.

4) 防災科学技術研究所：強震ネットワーク K-NET ホームページ, http://www.kyoshin.bosai.go.jp/

5) 気象庁, 気象業務支援センター: 強震波形データ CD-ROM (2004 年, 2005 年, 2006 年 $1-6$ 月).

6) 溜正俊, 铇田隆：免震建物の地震観測記録と振動解析結果, 平成 16 年新鼬 県中越地震被害調查報告会梗概集, 日本地震工学会ほか, pp. 111-116, 2004.

7) 境有紀, 中村有紀子, 大月俊典, 小杉慎司 : 2004 年新鼬県中越地震で発生し た地震動と建物被害の対応性，日本建築学会構造系論文集，No. 601, pp. 69-73, 2006.

8）時松孝次, 関口徹, 三浦弘之, 翠川三郎:強震記録から推定したK-NET·JMA 小千谷に㧍ける表層地盤の非線形性状, 日本建築学会構造系論文集, No. 600, pp. 43-49, 2006.

9) 特松孝次, 関口徹：K-NET - JMA 小千谷の強震記録に見られる土の非線形 性状と室内試験から求めた動的変形特性との関係, 日本建築学会構造系論 文集, No. 603,pp. 63-68, 2006.

10) 藤川智, 先名重樹, 藤原広行, 大井昌弘 : 2004 年新潟県中越地震の強震観測 点における表層地盤の地震動增幅, 日本地震工学会論文集, 第 6 巻, 第 3 号, pp. 27-42, 2006.

11) 新潟県中越地震水道現地調查団 (厚生労働省健康水道課) : 新潟県中越地震 水道被害調查報告書, 2004 .

12）関口徹, 新井洋, 時松孝次：小千谷市に扔引る建物被災地域の微動・地震動 特性評価, 第 12 回日本地震工学シンポジウム, pp. 1422-1425, 2006.
13）時松孝次, 新井洋:レイリー波とラブ波の振幅比が微動の水平鉛直スペクト ル比に与える影響, 日本建築学会構造系論文集, No. 511, pp. 69-75, 1998.

14）中村豊, 上野真: 地表面震動の上下成分と水平成分を利用した表層地盤特性 推定の試み, 第 7 回日本地震工学シンポジウム,pp. 265-270, 1986.

15) 新井洋, 関口徹, 時松孝次 : 2004 年新潟県中越地震後の K-NET · JMA 小千 谷に扔ける表層 S 波速度の回復過程, 第 12 回日本地震工学シンポジウム, pp. 1414-1417, 2006

16) Tokimatsu, K.: Geotechnical Site Characterization Using Surface Waves, Proc. IS-Tokyo'95 / Ist Intl. Conf. Earthquake Geotechnical Engineering, Tokyo, Vol. 3, pp. 1333-1368, 1997.

17) Capon, J.: High-Resolution Frequency-Wave Number Spectrum Analysis, Geophysics, Vol. 34, No. 1, pp. 21-38, 1969.

18）堀家正則：微動の研究について, 地震 2, 第 46 巻, pp. 343-350, 1993.

19) Okada, H.: The Microtremors Survey Method, Geophysical Monograph Series No. 12, Soc. Exploration Geophys. Japan, 155pp, 2004.

20) Arai, H., and K. Tokimatsu: S-Wave Velocity Profiling by Joint Inversion of Microtremor Dispersion Curve and Horizontal-to-Vertical (H/V) Spectrum, BSSA, Vol. 95, No. 5, pp. 1766-1778, 2005.

21) Yamanaka, H., K. Motoki, S. Fukumoto, T. Takahashi, N. Yamada, and K. Asano: Estimation of Local Site Effects in Ojiya City Using Aftershock Records of the 2004 Mid Niigata Prefecture Earthquake and Microtremors, Earth Planets and Space, Vol. 57, No. 6, pp. 539-544, 2005.

22) Schnabel, P. B., J. Lysmer, and H. B. Seed: SHAKE - A Computer Program for Earthquake Response Analysis of Horizontally Layered Sites, EERC Report, No. 72-12, 1972.

23) Lysmer, J., and R. L. Kuhlameyer: Finite Dynamic Model for Infinite Media, ASCE, EM4, pp. 859-877, 1969

24) Jennings, P. C.: Periodic Response of a General Yielding Structure, ASCE, Vol. 90, No. EM2, pp. 131-166, 1946.

25）福武毅芳, 松岡元: 任意方向単純せん断におけるダイレイタンシーの統一的 解採, 土木学会論文集, 第 412 号, III-12,pp. 143-151, 1989.

26）日本建築学会：入阴 - 建物と地盤との動的相互作用,pp. 236-260, 1996.

27）福武毅芳：土の多方向繰返しせん断特性を考慮した地盤・構造物系の三次 元液状化解析に関する研究, 名古屋工業大学博士論文, 1997.

28) Tokimatsu, K., S. Tamura and S. Kuwayama: Liquefaction Potential Evaluation Based on Rayleigh Wave Investigation and Its Comparison with Field Behavior, Proc. Second International Conference on Recent Advances in Geotechnical Earthquake Engineering and Soil Dynamics, pp. 357-364, 1991.

29）林康裕：性能等価応答スペクトルに基づく建築物の地震荷重評価, 第 11 回 日本地震工学シンポジウム, pp. 651-656, 2002.

30）須田達, 森井雄史, 林康裕, 鈴木祥之：地震被害に基づく木造建物の限界変 形性能の評価（2000 年鳥取県西部地震に基づく検討事例），日本地震工学 会大会 -2003 梗概集, pp. 32-33, 2003.

31）清水秀丸, 林康裕, 鈴木祥之, 斎藤幸雄, 後藤正美: 2003 年 7 月 26 日宮城県 北部の地震による被災木造住宅の構造的特徵と耐震性能, 日本建築学会構 造系論文集, No. 598, pp. 43-49, 2005 .

32）鈴木祥之, 中治弘行, 岩井哲, 北原昭男 : 在来構法木造住宅の実大水平力載 荷実験, 日本建築学会構造系論文集, No. 499, pp. 69-76, 1997.

33）林康裕, 北原昭男, 平山貴之, 鈴木祥之 : 2000 年鳥取県西部地震の地震動強 さの評価, 日本建築学会構造系論文集, No. 548, pp. 35-41, 2001.

34）木造軸組構法建物の耐震設計マニュアル編集委員会：伝統構法を生かす木 造耐震設計マニュアル－限界耐力計算による聇震設計・耐震補強設計法, 学芸出版社, $231 \mathrm{pp}, 2004$.

35）森井雄史, 林康裕, 更谷安紀子：耐震性能評価と地震被害経験に基づいた木 造住宅の地震時損傷度予測手法，地域安全学会論文集，No. 7, pp. 281-289, 2005.

36）林康裕, 更谷安紀子, 森井雄史：木造住宅の経年劣化と地域地震環境を考慮 した地震時損傷度予測手法, 日本建築学会構造系論文集, No. 615, pp. 77-84, 2007.

(2007年 4 月 10 日原稿受理，2007年 6 月 22 日採用決定) 